\title{
Time Varying Macroeconomic Risk and Industry Stock Returns: Empirical Evidence from India
}

\author{
Dr. T.G.Saji \\ Assistant Professor \\ Post Graduate Department of Commerce and Management Studies \\ Government College, Thrissur, Kerala, 680014, India \\ Tel: 91-94-4686-9214Ｅ-mail:sajthazhungal@gmail.com
}

Received: Nov. 4, 2013 Accepted: December 10, 2013 Published: December 10, 2013

doi:10.5296/ajfa.v5i2.4510 URL: http://dx.doi.org/10.5296/ajfa.v5i2.4510

\begin{abstract}
This paper searches further evidence for the relation between the time varying macroeconomic conditions and stock returns in India using monthly data during the post 2000 period. Unlike other research in the area, the study uses industry level stock price data on six sectors namely Banking, Energy, FMCG, Information Technology, Pharmaceuticals and Automobiles. Data availability and diverging business cycle sensitivity constitute the rationale behind the selection of industry groupings. Empirical methodology involves a multi-factor modeling using Generalized Auto Regressive conditional Heteroskedasticity (GARCH) model. The results of the study proved that the expected premium on stock market investments in India was time varying and has been affected by the time varying conditional volatilities of macroeconomic factors. The impact of economic changes found different across the industries and the sectoral variations in stock returns confirm the potentials of industry allocation for the diversification of investment risks.
\end{abstract}

Keywords: Macroeconomic Variables, Stock Returns, GARCH, Conditional Volatilities JEL Classification: C22, C32, E44 


\section{Introduction}

Discovering the forces that impel stock returns is a major topic of discussion among academics and practitioners. The stock price movement is highly exposed to the changes in fundamentals, among which the economic factors representing real and financial sectors seems to be dominant. The rationale behind such holding is that the real value of a stock almost equal to the present value of future cash inflows from its investments. The modern financial theory considers systematic factors as the prime sources of variations in stock returns. The specific nature of an economy along with its linkage with the external world often decide the size and patterns of cash inflows to its different sectors in changing economic cycles. Sometimes investment in stocks of worst industry at the expansion stage of an economy delivers better return than that the best industry in the declining stage delivers, hence a stock analyst should identify the key economic factors that influence the performance of particular sector and also its relative strength or weakness.

Several models explaining the relation between stock return and its determining factors are available today. The Capital Asset Pricing Model (CAPM) of Sharpe (1964) and Lintner (1965) explains the variation in stock returns as the linear function of changes in the market beta. These predictions have become the subject matter of investigation in many studies later. Much of the evidence proved empirical contradictions of CAPM model and they strongly challenged the ability of market return as the sole factor to explain the variations in stock returns. Most of these studies suggested the use of a multifactor approach to identify the extra market factors which cause price volatility in stock markets. This approach takes an assumption that the stock return are under the influence of a limited number of economic factors. The pioneer in that approach is Arbitrage Pricing Theory (APT) developed by Ross (1976). Roll and Ross (1980) modified APT in the form of a model capable to test its fitness. In addition to APT, a multi beta CAPM approach can also be used for discovering extra factors in addition to market return which contribute to stock returns volatility.

In practice, risk averters in financial markets want to forecast not only returns, but also volatility during their investments. On realizing this, now a day's consensus exists among the analysts as to the need of using conditional means and variance in financial econometric analysis. When forecasting expected returns, the investors should consider heteroskadasticity (Merton, 1980). Literature shows that the class of Generalized Auto Regressive conditional Heteroskedasticity (GARCH) successfully captures asset returns and volatility by allowing the means of asset returns to depend on their time varying variance as well as other contributory factors (Butt et al. (2010).

As an emerging economy, India has gained significant amount of economic growth during the post liberalization period. Being a cost efficient labor rich economy, India is able to capitalize the service sector boom, especially in IT and ITeS sector, in the global market. The economy continues to expand with service sector as its driving force. The economic expansion led to improved income distribution in the country, by this many sectors including Banking, Automobiles, and FMCG have benefitted much. The Global Financial Crisis badly affected the earnings of certain sectors like Pharmaceuticals; Information Technology etc... since their 
exposure to foreign markets are relatively more. The price fluctuations in crude oil market have affected the performance of energy sector. It is worthy to remember that almost all of these economic revolutions were happened during the post 2000 period. The governance and financial innovation practices during this period have brought in creditable makeovers which in turn fuelled the growth of an equity cult in India. Then Indian stock market shoots up which rejuvenated confidence to domestic investment base, at the same time augment foreign investment flows in to the country. On consolidating these facts researchers need to answer certain questions. Do the economic forces impact the sectoral stock returns in India symmetrically? If not, what are the economic factors critical in predicting stock return variability across the sectors? To answer these questions it is imperative to measure the stock return variations across industries under a transfigured economic frame.

The rest of the paper is organized as follows: Section 2 reviews related studies. Section 3 describes data and methodology employed in this study. Section 4 discusses the results of the analysis and Section 5 concludes the paper.

\section{Review of Literature}

A significant amount of empirical literature investigates the relations between the economic variables and stock returns by using multifactor asset pricing models in different country contexts. As a pioneering work in the area, Chen (1983) gave an economic interpretation to statistical factors. In their popular work, Chen, Roll and Ross (1986) use a six factor model based on monthly data for the period of 1953-1983 and found industrial production, risk premium and term structure premium as the significant determinants of stock returns in U.S market. Their model failed to capture the stock returns' relations with factors like market returns, changes in expected inflation, and unexpected inflation. Later Zhou (1999) confirmed the statistical significance of four out of six variables used by Chen et al. (1986) in predicting U.S stock returns. Mukherjee and Naka (1995), Wongbangpo and Sharma (2002), Chaudhari and Smile (2004), Majid and Yousof (2009), Gazi and Hisham (2010), Ibrahim (2011) and Ray (2012), all of these studies have found significant positive association between stock prices and economic activities in various countries.

Fama and French (1993) introduced a 'Three Factor Model' in the spirit of arbitrage pricing theory. They argued that the effects of size and book equity - to-market equity could be explained as manifestations of risk premiums. Using an arbitrage pricing type model they show that stocks with higher sensitivity on size or book-to-market factors have higher average returns. According to them risk is determined by sensitivity of a stock to three factors (1) Market portfolio, (2) a portfolio that reflects relative returns of small verses large firms and, (3) a portfolio that reflects relative returns of firms with high verses low book-to market ratio firms. They argued that even though size and book to market equity ratios are not direct factors affecting returns, they perhaps might be proxies for more fundamental determinants of risk. Thus they conclude that these patterns of returns are consistent with efficient market hypothesis in which expected returns depend solely on risk. Bae and Duvall (1996) applied multi-index CAPMs to explore the relationships of US aerospace industry stock returns to selected market and industry variables during the period $1982-1991$. The study found that the 
market returns represented by the S\&P 500 index and Department of Defense expenditures are significantly positively related to aerospace stock returns. Cauchie, Hoesli and Isakov (2002) investigated the determinants of stock returns in a small open economy in an Arbitrage Pricing Theory framework. The analysis is conducted with monthly data from the Swiss stock market over the period 1986-2000. They used data on industrial sector indices, as well as macro-economic data and found that Swiss equity returns are influenced by both global and domestic economic conditions. The results also show that the statistically determined factors yield a better representation of the determinants of stock returns than the macro-economic variables. Rehman and Saeedullah (2005) applied a multi-index model to relate the stock returns of Pakistan cement industry firms to selected market and industry variables. They found industry variables are insignificantly related to the stock returns of cement industry but they do increase the explanatory power of the model.

In Indian scene, Madhusoodanan (1997) conducted a study to find out the relationship between the expected return and risk by using portfolio method rather than the individual security approach. For the purpose, portfolios were formed to test their performance in the consequent period. Results indicated that the risk and expected return in the Indian market are not necessarily positively related. Moreover in Indian market, the investor rationality and risk aversion do not appear to be important. Sehgal (1997) empirically tested three-parameter Capital Asset Pricing Model in Indian capital market by taking monthly rates of return (adjusted for bonus, stock splits and right issues) for 80 securities included in BSE National Index. The evidence indicated that CAPM is not a suitable descriptor of asset pricing on the Indian capital market for the period of the study. Slope was found negative but insignificant for the total period, implying absence of any significant relationship between beta and average return. Malakar and Gupta (2002) took an effort to explain the major determinants of sectoral stocks in Indian stock market. Their sample consists of eight major cement companies India and study covered the period from 1968 to 1988. The study has found earnings per share and investment expenditure to be significant determinants of share price. Mishra (2004) examined the relationship between stock market and foreign exchange markets in India using Granger causality test and Vector Auto Regression technique .They used monthly data for stock return, exchange rate, interest rate and demand for money for the period 1992 to 2002 . The study found a unidirectional causality between the exchange rate and interest rate and also between the exchange rate return and demand for money. The study also suggested that there is no Granger causality between the exchange rate return and stock return Ahmed (2008) examined the nature of the causal relationships between stock prices and the key macro economic variables representing real and financial sector of the Indian economy for the period March, 1995 to March, 2007 using quarterly data. The results of the study revealed differential causal links between aggregate macro economic variables and stock indices in the long run. However it revealed that causal pattern is similar in both markets in the short run. The study results indicate that stock prices in India lead economic activity except movement in interest rate. Interest rate seems to lead the stock prices. Based on CAPM as theoretical framework and the samples of size varying from 182 companies to 544 companies for various estimations period between April 1991 to March 2006 Francy 
(2008) provides empirical validity of the Three factor model of Fama and French(1992) in determining stock returns in India. The explanatory power of the three-factor model was found to lie between 69 per cent and 90 per cent for the various portfolios constructed which shows that the three-factor model has captured the majority of the positive returns that had been left unexplained by the CAPM in Indian context.

Time variation in stock market volatility is also a matter of investigation for many researchers in different market context. Errunza and Hogan (1998) in their study, provide evidence for the impact of past variability of economic factors on European stock market volatility. Similar study was under taken by Mei and $\mathrm{Hu}$ (2000) based on real estate stock returns of some Asian countries and found that risk premium of Asian property stocks influenced significantly by macroeconomic risk factors. Bivariate GARCH M model of Fang and Miller (2002) measured the time varying conditional variances of stock market returns and currency depreciation in five emerging East Asian markets. Liow (2004) proved the expected risk premium on real estate stock in Singapore were time varying and correlated to time varying conditional volatilities of macroeconomic variables. In their comprehensive study Liow, Ibrahim and Huang (2006) extend the work of Liow (2004) to some more markets, Japan, Hong Kong and UK. Even though the study confirmed the validity of previous findings, it found that the impact of macroeconomic factors on property stock returns quite different across the markets. Joseph and Vezos (2006) by using an EGARCH model tried to capture the impact of interest rate movement and exchange rate changes on US banks stock returns. The results showed that market return contributed to the variation in stock returns and its sensitivity towards both interest rate changes and exchange rate fluctuations was not much significant. Butt, Rehman, Khan and Safwan (2010) under GARCH M framework examined the stock returns variations to specific economic variables by applying a multi factor model. The model applied on the stock returns of firms from two industries- banking and textile in Pakistan. The study found that economic exposure is higher at industry level than the firm level stock returns. In their study, Donadelli and Lucchetta (2013) found equity risk premium in emerging market is higher than that in developed markets. Their study also confirmed the time varying nature of emerging stock market excess returns.

On reviewing the available literature it is quite evident that the research on the impact of macroeconomic performance on the stock price behavior is not scanty in Indian context. But most of these studies provide a general measurement of stock return variations influenced by various economic factors. Surprisingly very few published research is found concerning the causality between the economic variables and sectoral stock returns in India. Moreover Indian corporate sector as well as stock market received significant growth during the post financial sector reform phase (second phase) of 2000. To the best of our knowledge, no exhaustive work on the impact of macroeconomic performance on stock returns of different industrial groupings covering this period in Indian context has not made so far. This paper ultimately attempts to discover which, if any, of the economic variables are of use in explaining the variability of industry stock returns in India. However this paper does not evaluate the stock return performance of a particular sector relative to that of others in terms of its sensitive change to a specific industry variable. 


\section{Data and Methodology}

\subsection{Data}

The researcher limits this study to selected six independent (macroeconomic) variables which once identified through literature review. Along with these economic variables, market return measured by the relative change in NSE Nifty is also used as independent variable. Industrial production index in India is compiling and publishing on monthly basis, hence it is used instead of GDP to give proxy for the domestic supply factors/national output. To gauge the money stock in the economy the most popularly used Broad Money Supply (M3) and to give proxy for interest rate prevailing in the economy 3 months' Treasury Bill (TB) rate has been used in this study. To account for inflation, the Whole Sale Price Index and to check the linkage with the external world, Rs/\$ exchange rate is used. To recheck the validity of some of the earlier studies finding that Foreign Institutional Investors is the crucial factor deciding the stock price behavior in India, FII net flows to India has also included in the data frame. Data selection takes into account the data availability and their accessibility within the available timeframe. Most of the macroeconomic variables under study is available on monthly basis only which restrict the study to choose monthly data. Required macroeconomic data were mainly obtained from RBI handbook on statistics and Economic Survey reports (various issues) published by Government of India. The data for Nifty was obtained from the website of National Stock Exchange.

Then, stock returns from six industries namely Banking, Energy, FMCG, Information Technology, Pharmaceuticals and Automobiles were considered based on the availability of the data. Monthly closing values of the indices representing these sectors were used for ascertaining the sector wise stock returns. Among these six indices, all five indices except, automobile are NSE indices. Since NSE is not publishing any Automobile sector index, the index representing Automobile stock movement has taken from Bombay Stock Exchange. Realty and Infrastructure indices could also not to be included as these indices have been compiled and published by stock exchanges in India since 2005 only, the inclusion of which definitely lack data consistency in comparison on time period basis. As many of the sector indices values are available from the financial year 2001-02 only, this part of analysis covered only nine years from that financial year to 2009-10.

\subsection{Empirical methodology}

The study relates the performance of six industrial stock returns in India with the macroeconomic performance of the country during the post 2000 period. It estimates five GARCH (Generalized Autoregressive Conditional Heteroskedasticity) equations separately to find out the sensitive relationship of each of the selected industrial stock returns with the macroeconomic performance of the country. The empirical procedure pursued in the study is detailed below:

\subsubsection{Unit root test}

Time series analysis must be stationary for producing most reliable results. A data series is said to be stationary if its mean and variance are constant (non-changing) overtime and the 
value of co variance between time periods depends only on the distance or lag between two time periods and not on the actual time at which the covariance is computed. Estimation using non-stationary data will lead to unreliable t-statistics, as the underlying time series would theoretically have infinite variances. So before initiating any type of advanced econometric techniques for the study, at first it should check the stationary property of the time series variables used in the study by performing unit root test. The study has followed the standard procedure of unit root testing by employing the Augmented Dicky Fuller (ADF) test. ADF test on the variables in level and first difference is employed to check for stationary.

\section{Augmented Dickey Fuller (ADF) Test}

ADF is a parametric method for controlling higher order correlation by assuming that the series follows an AR (p) process (Dickey and Fuller 1979, 1981). This process is done by adding lagged difference terms of the dependent variable to the right-hand side of the regression. The Augmented Dickey-Fuller test requires running a regression of the first difference of the series against the series lagged once lagged difference terms and a constant with a time trend such as:

$$
\Delta Y_{t}=\alpha_{0}+\beta_{0} t+\lambda Y_{t-1}+\gamma_{i} \sum_{i=1}^{m} \Delta Y_{t-1}+\varepsilon_{t}-------(1)
$$

Where $\Delta$ is the first difference operator, $\varepsilon_{t}$ is an error term, and $m$ is the number of lagged first differenced term and is determined such that $\varepsilon_{t}$ is approaching white noise. The $\mathrm{H}_{\mathrm{o}}$ hypothesize that $Y_{t}$ is non stationary time series (has a unit root) translates in to Hoe: $\lambda=0$. The output of the ADF test consists of the $t$ (tau) statistic on estimated coefficient of the lagged variable $(\lambda)$ and the critical values for the test of a zero coefficient. If the estimated ADF statistic is larger (in absolute) than its critical value then the null is rejected suggesting that the series is a stationary. The choice of optimal lag length used in the unit root tests is determined by applying Akaike (AIC) and Schwarz (SIC) information criteria.

\subsubsection{GARCH (Generalized Autoregressive Conditional Heteroskedasticity)}

Conventional econometric analysis takes homoskedasticity assumption or views the disturbance terms as constant over time (Asteriou and Hall, p. 249). But most of the 
financial data exhibit periods of unusually high volatility followed by more tranquil periods of low volatility. In such cases the assumption of homoskedasticity is very limiting, and in such instances it is preferable to examine patterns that allow the variance to depend upon its history.

Estimates a GARCH model $(\mathrm{GARCH}=$ Generalized Autoregressive Conditional Heteroskedasticity), either a univariate model or a multivariate model, if independent variables are selected, including the given exogenous variables. The conditional variance equation is shown below.

$$
h_{t}=\alpha_{0}+\sum_{i=1}^{q} \alpha_{i} \varepsilon_{t-i}^{2}+\sum_{j=1}^{p} \beta_{j} h_{t-j}
$$

The parameter $\mathrm{p}$ therefore represents the Generalized (or "AR") order, while q represents the regular ARCH (or "MA") order. If $\mathrm{p}$ is non-zero, q must also be non-zero otherwise the model is unidentified. However, one can estimate a regular ARCH model by setting q to a positive value and $\mathrm{p}$ to zero. The sum of $\mathrm{p}$ and $\mathrm{q}$ must be not greater than 5 .

\section{Results and Discussions}

\subsection{Industrial stock returns - Descriptive statistics}

Table 1 presents the summary statistics for the five industrial sector indices for the period 2002-2010. Minimum and maximum rate of return provided by each sector index during the period and their respective Mean, Standard Deviation (S.D) and Skewness are also reported. SD and Skewness are computed for explaining the volatility and normality of the distribution respectively. Lower rate volatility in the distribution of return indicates more consistency in market and lesser chance for investors to lose their money. Generally value for zero Skewness represents that the observed distribution is normally distributed. The Skewness coefficient, in excess of unity is taken to be fairly extreme (Chou 1969). 
Table 1. Industrial stock returns - Descriptive statistics

\begin{tabular}{|l|r|r|r|r|r|}
\hline & Minimum & Maximum & $\begin{array}{c}\text { Return on } \\
\text { annual basis }\end{array}$ & \multicolumn{1}{c|}{ S.D } & Skewness \\
\hline Banking & -26.66 & 44.53 & 28.80 & 10.53 & 0.200 \\
\hline Energy & -29.02 & 36.60 & 27.72 & 9.19 & -0.088 \\
\hline FMCG & -17.90 & 28.21 & 13.32 & 6.93 & 0.303 \\
\hline IT & -42.00 & 38.21 & 13.92 & 11.29 & -0.316 \\
\hline Pharmaceuticals & & & & & \\
& -24.38 & 16.48 & 20.02 & 7.14 & -0.534 \\
\hline *Automobiles & -26.92 & 31.80 & 23.16 & 9.28 & -0.002 \\
\hline
\end{tabular}

Compiled from NSE Industry indices data *BSE Auto Index data

The statistics shows that the return generating capacity of different sector stocks are not uniform during the study period. Moreover the variability of returns which is measured by both Standard Deviation and Range (difference between maximum and minimum of returns during a period) is also much different from industry to industry. When the Banking sector scrip delivered the highest return of 28.80 per cent to its investors, Energy sector delivered almost same scale of return with 27.72 per cent. Automobiles and Pharmaceuticals were produced returns at the rate of 23 per cent and 20 per cent respectively. The performance of Information Technology and FMCG stocks in terms of return were far behind of other sector indices. But in risk terms the performance of FMCG sector indices outperforms other sector indices. Pharmaceutical stocks also showed more consistency compared to the stocks of remaining sectors. Stability in delivering returns to investors by Energy sector is almost similar to that of Automobiles during this period. Information Technology and Banking sector stocks proved to be the most risky investments for investors with the standard deviations of 11.29 per cent and 10.53 per cent respectively. The variability in return from these sectors in terms of Range is also considerably high compared to other sectors. Here it is also very interesting to note that the return profile of the most risky stock investment among the group - Information Technology sector stocks is somewhat poor which further creates an impression that the return from stock investments of all sectors shall not always be commensurate with its risk profile. Investment in IT sector stocks in India has not been better rewarded for the level of the risk that its investors actually assumed during the period of the study.

It can also be seen that frequency distribution of all the indices except Energy and Automobiles are not normal, but none of them showed any extreme skewness. Skewness coefficient for both Energy and Auto sector returns almost equal to zero which one way help to say that market for these two sectors is relatively normal. When IT and Pharmaceutical indices showed moderate degree of negative skewness indicating the greater probability of large decreases in prices rather than rises, Banking and FMCG sectors showed low degree of positive asymmetry in its distribution of returns.

Thus the descriptive statistics on variance and skewness contribute to different volatilities across the industrial sectors in India. Consequently the base hypothesis in every efficient 
capital market that the stock returns and macroeconomic performance are normally distributed may not be validated. These findings suggest that stock returns and economic time series exhibit conditional heteroskedasticity and that a GARCH specification is appropriate for capturing the presence of time varying volatility.

\subsection{Unit Root test results}

ADF test is applied on all variables that is, on both stock returns and economic factors. In ADF unit root test, we test the null hypothesis that the time series has a unit root or it is non-stationary.

Table 2. Test results for Stationarity of variables

\begin{tabular}{|c|c|c|c|c|}
\hline \multirow[t]{2}{*}{ Variables } & \multicolumn{2}{|c|}{$\begin{array}{c}\text { Level } \\
\text { (with trend and intercept) }\end{array}$} & \multicolumn{2}{|c|}{$\begin{array}{c}\text { First Difference } \\
\text { (with trend and intercept) }\end{array}$} \\
\hline & Test statistic & P value & Test statistic & P value \\
\hline Energy & -3.8995 & $0.0121 * *$ & -4.6408 & $0.0008^{*}$ \\
\hline $\begin{array}{l}\text { Information } \\
\text { Technology }\end{array}$ & -2.2288 & 0.4729 & -4.8304 & $0.0004 *$ \\
\hline Pharmaceuticals & -2.5398 & 0.3087 & -4.9389 & $0.0001^{*}$ \\
\hline FMCG & -2.2088 & 0.4840 & -4.3231 & $0.0028^{* *}$ \\
\hline Banking & -3.3113 & $0.0643^{* * *}$ & -3.9479 & $0.0103^{* *}$ \\
\hline Auto & -2.9681 & 0.1413 & -2.7632 & $0.0824 * * *$ \\
\hline Nifty & -3.0524 & 0.1180 & -4.3760 & $0.0023 *$ \\
\hline Exchange rate & -3.4173 & $0.0490 * *$ & -3.9084 & $0.0117 * *$ \\
\hline $\mathrm{M}_{3}$ & -1.6895 & 0.7562 & -7.3649 & $0.0000^{*}$ \\
\hline WPI & -2.0260 & 0.5865 & -4.9822 & $0.0001^{*}$ \\
\hline TBR & -2.3104 & 0.4246 & -10.4551 & $0.0000^{*}$ \\
\hline IIP & -1.8458 & 0.6823 & -6.0065 & $0.0001^{*}$ \\
\hline FII & -5.4718 & $0.0000^{*}$ & -7.2943 & $0.0000^{*}$ \\
\hline
\end{tabular}

*significant at 1 per cent level $* *$ significant at 5 per cent level $\quad * * *$ significant at 10 per cent level

Table 2 summarizes the results of ADF unit root tests. On the basis of test statistics, only the banking and energy stock returns found stationary at levels with intercept and linear trend. Among the independent variables all the series except Foreign Institutional Investment net flows and exchange found non stationary at level. So it is reasonable to believe that these series are integrated of order 0 , hence $\mathrm{I}(0)$ variable. But the remaining stock returns and macroeconomic variables- TBR, WPI, and M3 are integrated of order one, I(1), as they 
become stationary with intercept and trend after their first differencing.

\subsection{GARCH results}

The stock performance of six sectors was analyzed at industry level. The fitted GARCH models estimate diverse pattern of relationship between industrials stock returns and the macroeconomic conditions in India. Both ARCH and GARCH terms are statistically significant for three sectors- Information Technology, Energy and FMCG; which establish the time varying characteristics of their stock returns volatility. Conditional volatility of stock returns of these sectors could be the function of both the lag of the squared residuals and lagged variances. Only GARCH term is statistically significant for the remaining sectors which provide the impression that the stock returns of Banking, Pharmaceuticals and Automobile sectors are the functions of their lag variances. The statistically significant relationship between risk (lag variances) and returns provide the evidence for the risk premium for the risk associated with the stock returns of all sectors.

Table 3. Macroeconomic Factors and Stock Returns: GARCH Results

\begin{tabular}{|c|c|c|c|c|c|c|c|c|c|c|}
\hline $\begin{array}{c}\text { Dependent } \\
\text { variable }\end{array}$ & Constant & Nifty & WPI & $\begin{array}{c}\text { Exchange } \\
\text { rate }\end{array}$ & IIP & M3 & FII(net) & T bill rate & ARCH & GARCH \\
\hline Information & $-1.9106 * * *$ & $4.7234 *$ & $-2.1437 * *$ & $1.8393 * * *$ & $1.8201 * * *$ & -0.4334 & -1.132 & $-2.2924 * *$ & $1.8549 * * *$ & $8.2768 *$ \\
\hline Technology & -0.056 & 0.0000 & -0.0321 & -0.0659 & -0.0687 & -0.6647 & -0.25764 & -0.0218 & -0.0636 & 0.0000 \\
\hline \multirow[t]{2}{*}{ Pharmaceuticals } & -0.1452 & $3.2217^{*}$ & -0.442 & 1.1025 & -1.4653 & 0.4545 & -0.9727 & 1.132 & 0.0206 & $9.5320 * * *$ \\
\hline & -0.8845 & -0.0013 & -0.6582 & -0.2703 & -0.1484 & -0.6495 & -0.3307 & -0.2576 & -0.9836 & -0.0508 \\
\hline \multirow[t]{2}{*}{ Energy } & 1.3086 & $7.1307^{*}$ & -0.2773 & 0.798 & -0.3886 & $-2.7577^{*}$ & $-12.4251^{*}$ & 0.8462 & $1.9534 * * *$ & $2.1497 * *$ \\
\hline & -0.1907 & 0.0000 & -0.7816 & -0.4249 & -0.6976 & -0.0059 & 0.0000 & -0.3875 & -0.0508 & -0.0316 \\
\hline \multirow[t]{2}{*}{ Banking } & $2.6917^{*}$ & 0.9629 & -0.7321 & -1.3642 & $-2.5641 * *$ & 0.5803 & -0.3126 & 1.0061 & 0.7593 & $3.9674 *$ \\
\hline & -0.0071 & -0.3356 & -0.4641 & -0.1725 & -0.0103 & -0.5617 & -0.7546 & -0.3144 & -0.4477 & 0.0000 \\
\hline \multirow[t]{2}{*}{ Automobiles } & 0.5038 & $-3.8297 *$ & 0.1149 & $-1.7957 * * *$ & 1.1311 & 0.0849 & -0.6721 & -1.1461 & 0.7617 & $4.8185^{*}$ \\
\hline & -0.6144 & -0.0001 & -0.9085 & -0.0725 & -0.258 & -0.9324 & -0.5015 & -0.2518 & -0.4462 & 0.0000 \\
\hline \multirow[t]{2}{*}{ FMCG } & 1.0082 & 0.0763 & -0.0541 & -0.6691 & -0.9006 & -1.2716 & -0.0035 & $1.8847 * * *$ & $2.3365^{* *}$ & $11.1522 *$ \\
\hline & -0.3133 & -0.9392 & -0.9569 & -0.6571 & -0.3678 & -0.2035 & -0.9972 & -0.0595 & -0.0194 & 0.0000 \\
\hline
\end{tabular}

(Figures given in parentheses indicate p value)

* significant at 1 per cent level

** significant at 5 per cent level

$* * *$ significant at 10 per cent level

Market exposure found as the most significant factor in determining stock returns in India. This is because market return has significant relationship with stock returns of the sectors other than Banking and FMCG. But Automobile stock returns have only negative impact by general market changes. Indian Banking and FMCG sectors performed relatively well even during the period of recession. When the growth of banking sector in the country is mainly due to the prudent RBI policies, the domestic market orientation insulates the FMCG sector from the 
economic downturns (Saji, Harikumar \& Kasim, 2013). This could be taken as the better explanation for the independence of the stock return of these two sectors from the changes in benchmark index.

GARCH estimation results also provide evidence for the diverging nature of stock returns exposure at industry level to the changes in economic factors. Wholesale Price Index is insignificant to stock returns of almost all sectors except that of Information Technology. This suggests that the rising inflation in the country often leaves the stock returns of most sectors being unaffected. However the inflationary conditions in the country pull down the performance of IT sector, hence its stock returns also. The fluctuations in value of Dollar against Rupee are affecting the stock returns of only two sectors, Information Technology and Automobiles. IT stock return is impacted positively by the depreciation of Indian Rupee. Indian IT Industry is more exposed to the export market (US and Europe) for their revenues (NASSCOM, 2008), hence the depreciation of Rupee enable it to make more earnings on dollar realizations. However the continuous depreciation of Rupee is causing a negative effect on stock returns of Automobile sector. Indian Automobile sector is depending heavily on foreign supplies for their input materials and assembling parts. The Rupee depreciation definitely brings in increased cost to the sector in rupee terms.

Industrial Production Index is positively related to the IT stock return and negatively related to Banking returns. Other sectors hold no causal relation with Index of Industrial Production. The positive relationship between IT stock returns and real output might be due to the dominant share of IT industry in the total Industrial production of India. The negative relationship between Banking stock returns and the total production in real sector shows the diversion of investible wealth from financial sector to real sector and vice versa. Money supply variable has shown insignificant relationship in almost sectors. The Broad money variable holds significant bearing only on Energy sector returns.

FII net flows are insignificant for almost all sectors, but have shown uniform behavior to stock returns in India. This external variable holds inverse relationship with the price changes in different sectors. However such relationship is significant for energy sector only. The insignificance of impact of FII on stock returns in India imples the strength of the domestic institutional investment base of the country which seems to be vital inputs for policymakers and regulators.

The interest rate is found negatively related to the stock returns of IT and Automobile sectors; nevertheless the impact is significant for only IT sector. The lower interest rate means lower cost of capital and better corporate earnings, which influence positively on share prices of these two sectors. With the stock returns of remaining sectors, the interest rate variable is positively related. Among these, except banking, all other sectors are more of defensive nature; hence rational to treat their stock returns independent of interest rate changes. The positive relationship of banking stock returns can be attributed to the nature of the industry being financial sector.

The market return contributes largely to the variations in stock returns of most of the sectors. Many of other economic variables also account for variations in stock returns even though the 
study observed their impact different across the sectors. So the inclusion of relevant economic variables along with the market return in a model definitely adds its explanatory power in estimating stock returns. This finding do up the utility of multifactor modeling in stock return estimation which earlier reported in studies like Chen et al (1986) and Butt et al. (2010).

\section{Conclusion}

The study investigates the relations between time varying macroeconomic conditions and industrial stock returns in India. The descriptive statistics on variance and skewness suggest that stock returns and economic time series exhibit conditional heteroskedasticity. Hence the GARCH specification is appropriate for capturing the presence of time varying volatility in India.

Multivariate asymmetric GARCH modeling administered in the study found evidence of linkage between macroeconomic conditions and industrial stock returns. However the impact of macroeconomic forces on stock returns is different from industry to industry. We find the evidence of maximum economic shocks on the stock returns of India's flagship industry, Information Technology sector. Except money supply and Index of Industrial Production, all other economic variables have strong bearing on the stock returns of Information Technology. When energy sector returns is impacted by money supply and Foreign Institutional Inflows, Automobile stock returns and FMCG stock returns are affected by the changes in exchange rate and interest rate respectively. The stock returns of financial services sector, banking sector, have shown negative responses to the increases in the total productivity of the country. The negative relationship between Banking stock returns and the total production in real sector revealed the diversion of investible wealth form financial sector to real sector and vice versa. Pharmaceutical stocks remain indifferent to the changes in the macroeconomic conditions.

Market return is the most significant factor which contributes to the variations in industrial stock returns in India. So we can expect the existence of risk premium at least for the market risk associated with the stock returns at industry level. Moreover the stock return volatility revealed time varying properties across the industries which basically could be the outcome of both the lag of the squared residuals and lagged variances in most cases.

Ultimately this study rationalizes the usefulness of a multifactor model in stock return estimation process. Along with the market return one has to include other economic variables also which is significant in explaining stock return variations. The nature and degree of relationship between stock returns and economic variables are different across the industries. Hence the investor of a particular sector has to design a model by including those variables which have sufficient explanatory power in determining his stock returns. The vigor of this paper is to supply with different models using relevant economic variables by judging their fitness and also by substantiating the reason for the inclusion of a particular variable in an estimation model.

The findings and implications of this study are limited to the post financial sector reform period 2000-2010 for India. Using alternative methodologies such as Cointegration, ARDL etc.., incorporating longer sample period and including other macroeconomic variables that 
may potentially affect stock returns might improve further analysis and significance of the study in this issue. Moreover the inclusion of data about other prominent emerging markets definitely makes the study more fruitful by better generalization of the results in emerging market context.

\section{References}

Asteriou, D., \& Hall, S.G. (2005). Applied Econometrics. London, Palgrave Macmillan.

Bae, C.S., \& Duvall, J.G. (1996). An Empirical Analysis of Market and Industry factors in Stock Returns of U.S. Aerospace Industry. Journal of Financial and Strategic Decisions, 9(2), 85-94.

Butt, B.Z., Rehman, K.U., Khan, M.A., \& Safwan, N. (2010). Do Economic Factors Influence Stock Returns? A Firm and Industry Level Analysis. African Journal of Business Management, 4(5), 583-593.

Cauchie, S., Hoesli, M. \& Isakov, D. (2002). The Determinants of Stock Returns in a Small Open economy. Working paper No. 80, FINRISK, National Centre of Competence in Research.

Chaudhary, K., \& Smile, S. (2004). Stock Market and Aggregate Economic Activity: Evidence from Australia. Applied Financial Economics, 14, 121-29. http://dx.doi.org/10.1080/0960310042000176399

Chen, N., Roll, R., \& Ross, S. (1986). Economic Forces and the Stock Market. Journal of Business, 59(3), 383-403. http://dx.doi.org/10.1086/296344

Chen, N.F. (1983). Some Empirical Tests of the Theory of Arbitrage of Pricing. Journal of Finance, 38(5), 1393-414. http://dx.doi.org/10.1111/j.1540-6261.1983.tb03831.x

Chou, Y.L. (1969). Statistical Analysts. London, Holt Rinehart and Winston.

Dickey, D.A., \& Fuller, W.A. (1979). Distribution of the Estimators for Autoregressive Time Series with a Unit Root. Journal of American Statistical Association, 74, 427-31.

Dickey, D.A., \& Fuller, W.A. (1981). Likelihood Ratio Statistics for Autoregressive Time Series with a Unit Root. Econometrica, 49, 1057-72. http://dx.doi.org/10.2307/1912517

Donadelli, M., \& Lucchetta, M. (2013). Stock Market Premia: Some evidence from Industrial Stock Market Data. Asian Economic and Financial Review, 3(4), 398-422.

Errunza, V., \& Hogan, K. (1998). Macroeconomic Determinants of Stock Market Volatility. European Journal of Financial Management, 4(3), 361-377. http://dx.doi.org/10.1111/1468-036X.00071

Fama, E.F., \& French, K.R. (1992). The Cross-Section of Expected Stock Returns. Journal of Finance, 47, 427-465. http://dx.doi.org/10.1111/j.1540-6261.1992.tb04398.x

Fama, E.F., \& French, K.R.(1993). Common Risk Factors in the Returns of Stock and Bonds. Journal of Financial Economics, 33, 3-56. http://dx.doi.org/10.1016/0304-405X(93)90023-5 
Francy, T.V. (2008). Mean Variance approach of Portfolio Management: An empirical analysis of Indian experience. Unpublished Doctoral Dissertation, Mahatma Gandhi University, India.

Gazi, M.H., \& Hisham, A. (2010). Can Macroeconomic Factors Explain Equity Returns in the Long Run? The Case of Jordan. Draft 4-15/05/2010, School of Economics and Finance, University of Western Sydney, Australia.

Ibrahim, M.H. (2011). Stock Market Development and Macroeconomic Performance in Thailand. Inzinerine Ekonomika-Engineering Economics, 22(3), 230-240.

Joseph, L.N., \& Vezos, P. (2006). The Sensitivity of US banks' Stock Returns to Interest Rate and Exchange Rate Changes. Managerial Finance, 32(2), 182-199. http://dx.doi.org/10.1108/0307435061064193

Lintner, J. (1965). The Valuation of Risk Assets and the Selection of Risky Investments in Stock Portfolios and Capital Budgets. Review of Economics and Statistics, 47(1), 13-37. http://dx.doi.org/10.2307/1924119

Liow, K.H. (2004). Time Varying Macroeconomic Risk and Commercial Real Estate: an Asset Pricing Perspective. Journal of Real Estate Portfolio Management, 10(1), 47-58.

Liow, H.K., Ibrahim, F.M., \& Huang, Q. (2006). Macroeconomic Risk Influences on the Property Stock Market. Journal of Property Investment Finance, 24(4), 295-323. http://dx.doi.org/10.1108/14635780610674507

Malakar, B., \& Gupta, R. (2002). Determinants of Share Price- A System Approach: The Modified Model. Finance India, 16(4), 14-19.

Madhusoodanan, T.P. (1997). Risk and Return: A New Look at the Indian Stock Market. Finance India, 1(2), 285-304.

Majid, S.M., \& Yusuf, M.R.(2009). Long-run Relationship between Islamic Stock Returns and Macroeconomic Variables. Humanonics, 25 (2), 127-41.

Mei, J. \& Hu, J. (2000). Conditional Risk Premiums of Asian Real Estate Stocks. Journal of Real Estate Financial Economics, 21(3), 297-313. http://dx.doi.org/10.1023/A:1012008004402

Merton, R.C. (1980). On Estimating the Expected Return on the Market. Journal of Financial Economics, 8, 323-361. http://dx.doi.org/10.1016/0304-405X(80)90007-0

Mishra, A.K. (2004). Stock Market and Foreign Exchange Market in India: Are they Related? South Asia Economic Journal, 209-232. http://dx.doi.org/10.1177/139156140400500202

Mukherjee, T.K., \& Naka, A. (1995). Dynamic Relations between Macroeconomic Variables and the Japanese stock market: An Application of a Vector Error Correction Model. Journal of Financial Research, 18, 223-37. 
NASSCOM. The IT Industry in India - Strategic 2008 Review

Ray, S. (2012). Testing Granger Causal Relationship between Macroeconomic Variables and Stock Price Behavior: Evidence from India. Advances in Applied Economics and Finance, 3(1), 470-481.

Ross, S.A. (1976). The Arbitrage Theory of Capital Asset Pricing. Journal of Economic Theory, 13(4), 341-60. http://dx.doi.org/10.1016/0022-0531(76)90046-6

Roll, R., \& Ross, S.A (1980). An Empirical Investigation of the Arbitrage Pricing Theory. Journal of Finance, 35(5), 1073-103. http://dx.doi.org/10.1111/j.1540-6261.1980.tb02197.x

Rehman, K., \& Saeedullah, M. (2005). Empirical Analysis of Markets and Industry Factors in Stock Returns of Pakistan Cement Industry. Journal of Independent Studies and Research, 3(2), 13-20.

Saji, T.G, Harikumar, S., \& Kasim, C.M. (2013). The Global Financial Crisis and the Performance of the Indian Corporate Sector: A Firm level Analysis. Indian Journal of Finance,7(5), 14-23

Sehgal, S. (1997). An Empirical Testing of Three Parameter Capital Asset Pricing Model in India. Finance India, 11(4), 424-442.

Shahid, A. (2008). Aggregate Economic Variables and Stock Markets in India. International Research Journal of Finance and Economics, 14, 141-64.

Sharpe, W.F. (1964). Capital Asset Prices: A Theory of Market Equilibrium under Conditions of Risk. Journal of Finance, 19, 425-42.

Trivedi, P., \& Nair, A. (2003). Determinants of FII Investment Inflow to India. Conference Paper, IGDRA, Mumbai. January 30-February 1.

Wongbangpo P., \& Sharma, S.C. (2002). Stock Market and Macroeconomic Fundamental Dynamic Interactions: ASEAN-5 Countries. Journal of Asian Economics, 13, 27-51. http://dx.doi.org/10.1016/S1049-0078(01)00111-7

Zhou, G. (1999). Security factors as linear combinations of economic variables. Journal of Financial Markets, 2(4), 403-432. http://dx.doi.org/10.1016/S1386-4181(99)00008-7

Merton, R.C. (1980). On Estimating the Expected Return on the Market. Journal of Financial Economics, 8, 323-361. http://dx.doi.org/10.1016/0304-405X(80)90007-0 